\title{
Editorial preface to the OJAKM special issue on knowledge management: Research, organization, and applied innovation
}

\author{
Special Issue Editors: \\ Chiara Bartolacci, University of Pisa, Italy, chiara.bartolacci@live.it \\ Federico Niccolini, University of Pisa, Italy, federico.niccolini@unipi.it \\ Meir Russ, University of Wisconsin - Green Bay, USA, russm@uwgb.edu
}

\section{Introduction}

This Special Issue of the Online Journal of Applied Knowledge Management (OJAKM), titled on "Knowledge Management: Research, Organization and Applied Innovation" attempts to give an account of some of the most insightful studies about organizational knowledge and learning, as well as some innovative and useful applications presented at the Knowledge Management (KM) Conference 2018. The KM Conference was held by the International Institute for Applied Knowledge Management (IIAKM) on the campus of the University of Pisa in June 2018, and was conceived as a dialectical context in which scholars from 15 nations and different continents exchanged ideas and perspectives on the more recent theoretical developments along with applications of the articulated, varied, and multifaceted themes of KM.

The dialogue has nourished an already rich and challenging field of KM study. Indeed, the pivotal role of KM has been widely acknowledged by both researchers' and practitioners' community (Davenport \& Prusak, 1998; Spender \& Grant, 1996). In facts, in the last decades, studies and theoretical contributions claiming the importance of knowledge and KM for organizations to be successful in the knowledge-driven economy, have been exponentially multiplying in international conferences, specialized journals and world-wide workshops. Also, many practical research works have been developed, moving the focus to innovation as a distinctive key factor in competitions (e.g., Teece, 2007). As a result, KM's relevance has flourished and it has shifted from being a branch of a wider discipline (i.e. Organizational Science) to a discipline of itself. This Special Issue of OJAKM is focusing on the unique aspects of KM in the context of innovation, specifically in the knowledge-driven economy.

What is interesting about knowledge, is its never-ending dynamism and its potential limitlessness (Maturana \& Varela, 1991). By definition, it would always be possible to enlarge the corpus and scope of knowledge, according to new tools and instruments, new methodologies and approaches, new perspectives and focuses, technologies and discoveries, as well as applications and issues (Alavi \& Leidner, 2001). Indeed, knowledge is a prominent topic in wide and heterogeneous research fields, while remaining so in the future (Hamel, 2008). Doing research in knowledge implies considering not just the theoretical speculations and models, but also the innovative applications and implications in contemporary world, 
society, communities, organizations and individuals (Leonard-Barton, 1995). It contemplates also a meta-research work about knowledge future scenarios, that is to say, to study and analyze the research activities and processes themselves including key question such as: how these studies and research undertakings have been carried out, along with in which directions such studies are leading or will lead in the future (Lucio-Arias \& Leydesdorff, 2009). Knowledge is somehow autopoietic (Luhmann, 1986), self-referencing, constantly reshaping itself, and redefining its own boundaries (Russ, Fineman \&Jones, 2010).

What we hope to accomplish with this Special Issue is to provide a representative collection of the most significant works presented at the "Knowledge Management: Research, Organization and Applied Innovation" KM2018 Conference regarding innovation, and offer a heterogeneous picture of the state of the art when it comes to the field of KM. Obviously, we acknowledge that this issue is not exhaustive, yet we think this could be a valuable addition to the body of knowledge on topics in contemporary day-to-day organizational and personal life. We trust this issue will be resounding, useful, and relevant to diverse audiences. From data to knowledge, from individuals to organizations and societies, from KM to learning processes: the key to interpretation of knowledge and innovation are a great variety, difficult to enlist, and sometimes in contrast one with another (Russ, 2018).

The issue starts with the article entitled "Security policy and data protection awareness of mobile devices in relation to employees' trusting beliefs". The paper aims to build a research model to examine the impact of security policy awareness and data protection awareness of mobile devices on employees' trust belief. In doing so, Alex Koohang, Kevin Floyd, Neil Rigole, and Joanna Paliszkiewicz administered a survey instrument to a sample in various organizations in the USA and analysed the collected data using Partial Least Squares Structural Equation Modeling (PLS-SEM).

The volume goes on with the paper titled "Knowledge donation and knowledge collection patterns in a Free Software Community", with which Andrea R. Balle, Carla Curado, and Mírian Oliveira enquired knowledge sharing within a free software community (FSC). They present a qualitative study to understand which combinations of tools and activities lead to knowledge sharing, obtaining alternatives configurations leading to both the outcomes and their absence.

The issue continues with the paper named "The Effects of Gamification Elements in elearning Platform", which examines in what manner gamification elements affect the elearning experience in software studies. To do so, Ruti Gafni, Dafni Biran Achituv, Shimon Eidelman, and Tomer Chatsky performed a controlled statistical experiment with two variants (termed as A/B test) based on two similar e-learning platforms, one of which included gaming elements, and compared the results.

Next, the article titled "Open government data, the case of Polish public sector" presents the idea of open government data along with the benefits and threats resulting from using open data for government entities. Thanks to participant observation, Jędrzej Wieczorkowski and Ilona Pawełoszek describe the results of their research on availability of the open data in Poland with particular emphasis on Central Repository for Public Information (CRPI). 
Subsequently, the volume introduces the article entitled "Prosumers knowledge sharing to develop and manage products". The paper aim is to advance the research on prosumers knowledge sharing with enterprises and public organizations by examining and better understanding what knowledge about products prosumers share and would like to share in order to improve products. To do so, Ewa Ziemba, Monika Eisenbardt, and Roisin Mullins used $a$ questionnaire survey among Polish and UK-based prosumers.

Finally, the issue is closed by the paper titled "Assessing the Effectiveness of IPTEACES eLearning Framework in Higher Education: Fundação Dom Cabral - a Brazilian Perspective", that reports the application of the IPTEACES Framework in FDC Executive MBA. Nuno Pena, Paula Simões, Lília Mascarenhas, and Flávia Alvim utilized qualitative and quantitative techniques to evaluate this instructional design framework for online corporate learning in Brazil, which could enable an integrated implementation of an appropriate learning strategy for different learners.

During this path we prepared for you, one important value of knowledge is when it is shared, and hence research seeks for effective ways to share or pass knowledge (Szulanski, 1996), to extract, store or retrieve data and knowledge, as well as to collect and interpret information (e.g., Stahl, \& Buckles 2016; Ziemba, Eisenbardt, Roisin, \& Grabara, 2017). Other times knowledge is considered as an asset to be effectively exploited, thereby research aims at studying tools, instruments, spaces, platforms, or methods to do so (e.g., Soniewicki, 2017; Niccolini, Bartolacci, Cristalli, \& Isidori, 2018). Nonetheless, knowledge has to be considered something to be secured because of its economics, legal, personal value, so research enquires conditions, instruments, and methods to do so (e.g., Carlton, \& Levy, 2017; Koohang, 2017). This is so much more of value and importance in the knowledge-driven economy than ever before.

In any of these cases, what we wish to highlight is that, although nowadays the places related to knowledge and innovation are more often virtual spaces (Bartolacci, Cristalli, Isidori, \& Niccolini, 2016; Melon, Levy, \& Dringus, 2016), including augmented reality and virtual reality, data at the ontological level that is usually taken into account. Moreover, computers, networks, databases, and AI systems are more frequently the producers of these data, while humans do still play an essential role in knowledge creation and innovation (Makridakis, 2017; Sun, 2018). Actually, humans are imperative to knowledge and research in the field (Polanyi, 1967; Nonaka, \& Toyama, 2005)., which must always be ultimately related to human beings as long as creativity and innovation are of value (Russ, 2016; Russ, Fineman \& Jones, 2010).

\section{References}

Alavi, M., \& Leidner, D. E. (2001). Knowledge management and knowledge management systems: Conceptual foundations and research issues. MIS Quarterly, 25(1), 107-136.

Bartolacci, C., Cristalli, C., Isidori, D., \& Niccolini, F. (2016). Ba virtual and interorganizational evolution: a case study from a EU research project. Journal of Knowledge Management, 20(4), 793-811. 
Carlton, M., \& Levy, Y. (2017). Cybersecurity skills: Foundational theory and the cornerstone of Advanced Persistent Threats (APTs) mitigation. Online Journal of Applied Knowledge Management, 5(2), 16-27.

Davenport, T. H., \& Prusak, L. (1998). Working knowledge: How organizations manage what they know. Boston, MA: Harvard Business Press.

Hamel, G. (2008). The future of management. Human Resource Management International Digest, 16(6). doi.org/10.1108/hrmid.2008.04416fae.001

Koohang, A. (2017). Social media sites privacy concerns: Empirical validation of an instrument. Online Journal of Applied Knowledge Management, 5(1), 14-26.

Leonard-Barton, D. (1995). Wellsprings of knowledge: Building and sustaining the sources of innovation. Boston, MA: Harvard Business Press.

Luhmann, N. (1986). The autopoiesis of social systems. Sociocybernetic paradoxes, 6(2), 172-192.

Lucio-Arias, D., \& Leydesdorff, L. (2009). The dynamics of exchanges and references among scientific texts, and the autopoiesis of discursive knowledge. Journal of Informetrics, 3(3), 261-271.

Makridakis, S. (2017). The forthcoming artificial intelligence (AI) revolution: Its impact on society and firms. Futures, 90, 46-60.

Maturana, H. R., \& Varela, F. J. (1991). Autopoiesis and cognition: The realization of the living (Vol. 42). Springer Science \& Business Media.

Melon, E., Levy, Y., \& Dringus, L. P. (2016). A study on the success of group formation and cohesiveness in virtual teams using computer-mediated communications. Online Journal of Applied Knowledge Management, 4(1), 62-81.

Niccolini, F., Bartolacci, C., Cristalli C., \& Isidori D. (2018). Virtual and inter organizational processes of knowledge creation and $\mathrm{Ba}$ for sustainable management of rivers. In $\mathrm{M}$. Russ (Ed), Handbook of Knowledge Management for Sustainable Water Systems, pp. 261-285. Hoboken, NJ: Wiley.

Nonaka, I., \& Toyama, R. (2005). The theory of the knowledge-creating firm: subjectivity, objectivity and synthesis. Industrial and corporate change, 14(3), 419-436.

Nonaka, I. (1991). The knowledge-creating company. Harvard Business Review, 69(6), 96104.

Polanyi, M. (1967). The tacit dimension. London, UK: Routledge \& Kegan Paul.

Russ, M. (2018). Introduction and a theoretical framework for Knowledge Management for Sustainable Water Systems. In M. Russ (Ed.) Handbook of Knowledge Management for Sustainable Water Systems. Hoboken, NJ: John Wiley \& Sons, Inc., pp. 1-12.

Russ, M. (2016). The probable foundations of Sustainabilism: Information, energy and entropy based definition of capital, Homo Sustainabiliticus and the need for a "new gold.” Ecological Economics, 130, 328-338. doi.org/10.1016/j.ecolecon.2016.07.013 
Russ, M., Fineman, R., \& Jones, J. K. (2010). Conceptual theory: What do you know? In M. Russ, (Ed.) Knowledge Management Strategies for Business Development: 1-22. Hershey, PA: Business Science Reference.

Soniewicki, M (2017). The importance of knowledge management systems for service industry companies operating locally and internationally. Online Journal of Applied Knowledge Management, 5(2), 76-91.

Spender, J. C., \& Grant, R. M. (1996). Knowledge and the firm: Overview. Strategic Management Journal, 17(SI), 5-9.

Stahl, B., \& Buckles, B. (2016). Replicative indwelling: Mitigating lost knowledge through accelerated experiential exposure. Online Journal of Applied Knowledge Management, 4(2), 110-127.

Sun, Z. (2018). Imaginational Intelligence: A new frontier for innovation, creativity and intelligence development in the age of big data, BAIS no. 1802, PNG University of Technology.

Szulanski, G. (1996). Exploring internal stickiness: Impediments to the transfer of best practice within the firm. Strategic Management Journal, 17(S2), 27-43.

Teece, D. J. (2007). Explicating dynamic capabilities: The nature and microfoundations of (sustainable) enterprise performance. Strategic Management Journal, 28(13), 13191350.

Zahra, S. A., \& George, G. (2002). Absorptive capacity: A review, reconceptualization, and extension. Academy of Management Review, 27(2), 185-203.

Ziemba, E., Eisenbardt, M., Roisin, M., \& Grabara, D. (2017). Investigating incentives that encouraged and can encourage Polish and UK-based prosumers to engage in knowledge sharing. Online Journal of Applied Knowledge Management, 5(1), 72-100.

\section{Editors' Biographies}

Chiara Bartolacci got her Ph.D. in Economics and Management from the Department of Economics and Law, Università degli Studi di Macerata, Italy, and she was a Visiting Ph.D. at Gothenburg Research Institute, University of Gothenburg. She cooperated with the Department of Economics and Management, University of Pisa, Italy. Her main research interests are related to knowledge management and storytelling in organizations.

Federico Niccolini is Associate Professor of Organizational Science at the Department of Economics and Management, University of Pisa and Associate Faculty at Colorado State University. His research interests focus on knowledge management, organizational vision and culture, protected areas management and organization, organizational dynamics related to sustainable development.

Meir Russ is a Professor in Management at the Austin E. Cofrin School of Business at the University of Wisconsin--Green Bay. His research interests include human capital valuation methods, knowledge-based strategies and the new-knowledge based economic development 
among others. Prof. Russ is at present the Chief Editor of Online Journal of Applied Knowledge Management (OJAKM). He also is the Frederick E. Baer Professor in Business and the Philip J. and Elizabeth Hendrickson Professor in Business. 